\title{
Effects of Nutrient Flushing on Production and Reproductive Performance of Teddy Goats (Capra hircus)
}

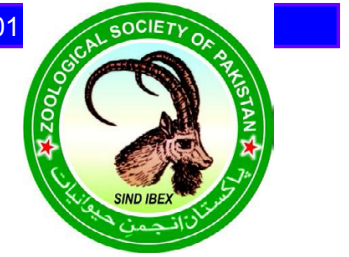

\author{
Aftab Shaukat ${ }^{1,2, *}$, Tauseef ur Rehman ${ }^{3}$, Rizwan Shukat ${ }^{4}$, Shahid Ali Rajput ${ }^{5}$, \\ Shadab Shaukat ${ }^{6}$, Muhammad Ahsan Naeem ${ }^{2,5,8}$, Mubashar Hassan ${ }^{2,5}$, Tabassam Fatima ${ }^{2,5}$, \\ Fayyaz Ahmad ${ }^{1}$, Muhammad Usman Saleem ${ }^{7}$, Fatima Arooj ${ }^{1}$, Ashar Mehfooz ${ }^{2}$ and Anas Sarwar Qureshi ${ }^{2}$
} ${ }^{1}$ Livestock Production Research Institute Bahadurnagar, Okara, Pakistan

${ }^{2}$ Faculty of Veterinary Sciences, University of Agriculture, Faisalabad, Pakistan

${ }^{3}$ University College of Veterinary and Animal Sciences, The Islamia University of Bahawalpur, Pakistan

${ }^{4}$ Faculty of Food, Nutrition \& Home Sciences, University of Agriculture, Faisalabad ${ }^{5}$ College of Veterinary Medicine/College of Animal Science and Technology, Huazhong Agricultural University, Wuhan 430070, People's Republic of China

${ }^{6}$ Department of Plant Breeding and Genetics, College of Agriculture, University of Sargodha, Sargodha

${ }^{7}$ Department of Biosciences, Faculty of Veterinary Sciences, Bahauddin Zakariya University, Multan, Pakistan

${ }^{8}$ College of Veterinary and Animal Sciences (Narowal), University of Veterinary and Animal Sciences, Lahore, Pakistan

\section{A B S T R A C T}

A study was conducted to assess the effect of flushing on reproduction performance (kidding type and fertility percentage) and production performance (birth weight, weaning weight of offspring and health of does). Eighty teddy does were randomly divided into two groups $(n=40)$ viz $T_{1}$ and $T_{2}$ as control group and test group, respectively. Flushing ration $250 \mathrm{~g}$ and $500 \mathrm{~g}$ with crude protein $17.5 \%$ and metabolizable energy $2.9 \mathrm{Mcal} / \mathrm{kg}$ was offered to does for one month prior and post breeding season (15 September-30 October). Does were weighed at the start of breeding season $\mathrm{T}_{2}(\mathrm{BW}=29.18 \pm 0.21 \mathrm{~kg})$ and $\mathrm{T}_{1}(\mathrm{BW}=28.93 \pm 0.53 \mathrm{~kg})$, respectively. All the does were sent for grazing of jantar fodder for four hours daily and were sheltered during the rest time in different pens with separate feeding during the whole experimental period. Ad libitum supply of fresh clean drinking water was made available round the clock. Exposed does were mated naturally and bucks were inducted to the exposed does for 30 minutes at morning and evening daily for teasing purpose to identify does in estrus, while separate them for breeding with enlisted buck. Mean values of Fertility rate and kidding rate in $\mathrm{T}_{1}$ and $\mathrm{T}_{2}$ were $75 \%$ vs $85 \%$ and $150 \%$ vs $176 \%(\mathrm{p}<0.01)$ showing significantly higher rate is in $T_{2}$ group. The birth weight and weaning weight of the kids in $T_{1}$ and $T_{2}$ group were $1.56 \pm 0.02 \mathrm{~kg}$ vs $1.87 \pm 0.04 \mathrm{~kg}$ and $9.0 \pm 0.21 \mathrm{~kg}$ vs $10.45 \pm 0.18 \mathrm{~kg}$, respectively showing better results in group $\left(\mathrm{T}_{2}\right)$. Effect of flushing on type of birth was observed significant at Chi-square value of $9.138 \mathrm{p}$-value of 0.010 showing higher number of twin and triplet birth in test group. Furthermore, the study of growth of kids revealed a better Average daily gains in $T_{2}$ than in $T_{1}$ indicating the long term carryover effect of flushing on the body weight gains of teddy goat kids.

Article Information
Received 30 March 2019
Revised 30 May 2019
Accepted 11 June 2019
Available online 16 January 2020
Authors' Contribution
AS, FA and RS conceived, designed
and performed the experiments,
interpreted the data. All other
authors helped in preparation of the
manuscript. AS, FA, RS and SS wrote
the manuscript.
Key words
Flushing, Birth weight, Body weight
gain, Teddy goat

\section{INTRODUCTION}

$\mathrm{P}$ akistan is blessed with a huge population of livestock including cattle, buffalo, goat and sheep approximately 184.4 million heads (Pakistan Economics Survey, 2017). Livestock is well adapted to subtropical environment, tolerant to endemic diseases and efficient converters of poor quality forages into valuable products like milk, meat,

\footnotetext{
* Corresponding author: aftabshuakat40@gmail.com 0030-9923/2020/0002-0457 \$ 9.00/0
}

Copyright 2020 Zoological Society of Pakistan skin, hides, bone and blood (Younas and Yaqoob, 2005). There is an utmost need to increase the livestock production potential to fulfill the growing demands of ever increasing population for livestock products (Celik, 2019).

Pakistan stands at 3rd number with 72.4 million goat population after China and India, and is continuously increasing since the past 15 years producing 701 thousand tons of mutton in the previous year (GoP, 2017). The success of a sheep and goat business depends on the number of lambs and kids raised, weaned, and marketed each year. The percentage of ewes and does conceived early 
in the breeding season, the lambing/kidding and weaning percentages are some of the most important factors influencing profits in the sheep and goat business. In other words, production is equal to reproduction. Like sheeps, goats also have potential for multiple ovulations, but this ability may be reduced by insufficient nutrition supplied. Nutrition directly influences fertility through mechanisms such as the development of oocytes, egg-laying, and fetal survival. It indirectly affects such behavior through blood metabolites and hormones (Robinson et al., 2006). Economically speaking, fertility and reproductive behavior are considered as the most prominent characteristics in livestock breeding. Moreover, they are regarded as the most important determining factors for the efficiency of livestock breeding, conservation of species and genetic advances (Ahmad Fazel et al., 2014).

Since nutritional requirements vary throughout the reproductive cycle, strategic feed supplementation can also be an important tool to improve reproductive efficiency. Nutrition is generally recognized as a significant regulator of reproduction (Smith and Akinbamijo, 2000) and improvement in the nutritional status of the does particularly preceding mating (flushing) is known to increase fertility in small ruminants due to dynamic effects of nutrition on ovulation rate (Kusina et al., 2001). Flushing ration usually contains high proteinaceous and high calorific values. This ration is offered to animals one month prior and post breeding season by which does not only fortify the nutritional deficiencies but also improve the fertility percentage, more does will be exposed to bucks and increase the kidding percentage. Flushing has also been reported to increase the body condition and weights of does, it does not only improve at mating (static effects) but also during their post-partum period (Titi et al., 2008).

Pakistan has 25 recognized indigenous breeds of goat (Hasnain, 1985; Kuthu et al., 2013), and goats are thought as the chief source of income for Pakistan via production of meat, milk and skin (Zubair et al., 2016). Population of teddy goats (Capra hircus) in Pakistan is 13.2 million heads (GOP, 2014). Among different breeds of goat, teddy goat also stands among famous breeds of goats in Pakistan. Home tract of teddy goat is Punjab province but it is also found in Azad Kashmir and northern parts of Pakistan due to docile in nature, small size, easy handling, and low feed intake. Teddy goats considered to have advantage upon all local breeds of goats to thrive in severe weather conditions of different environments (Kuthu et al., 2013). In tropical and subtropical areas of Pakistan, most of the teddy goats do not follow seasonal breeding pattern and breed round the year. This increase the difficulties of management in commercial flocks and high kid mortality have been observed during severe seasons. The progressive farmers have adopted hormonal therapies and controlled breeding pattern for specific seasons (once a year) for convenience in management. Small ruminants breed throughout the year, which result in overall poor survival of dams and kids, reduced reproductive and productive performances especially during late pregnancy and resulting kidding fall into periods with insufficient forage availability (Karikari and Blasu, 2009). Hence, breeding strategy is potentially advantageous both in terms of improved reproductive activity of the does and the growth performance of kids. So, present project was designed with objectives of accelerating reproductive activity of teddy goats and growth performance of kids. Here, we investigated the effect of flushing on production and reproduction performance in teddy goat, Capra hircus.

\section{MATERIALS AND METHODS}

The study was carried out at Livestock Production and Research Institute (LPRI), Bahadurnagar, Okara, Pakistan, that is situated at latitude $30^{\circ} 48^{\prime} 4.97^{\prime \prime}$ (North) and longitude $73^{\circ} 26^{\prime} 54$ (East), at an altitude of $105 \mathrm{~m}$ $(344 \mathrm{ft})$ above the mean sea level with area of $199 \mathrm{~km}^{2}$, average temperature $24.5^{\circ} \mathrm{C}$. The least rainfall is about $2 \mathrm{~mm}$ during October, with higher precipitation (Av $85 \mathrm{~mm}$ ) is in July.

A total of 80 healthy breedable teddy does (Av. age of 2-3 years) and a live body weight of $29 \pm 1 \mathrm{~kg}$ were randomly divided into two groups $\left(T_{1}\right.$ and $\left.T_{2}\right)$ of 40 in each group. These animals grazed available fodder of berseem and jantar in nearby field area for four hours ( 9 am to 13 pm) daily then stall feeding with chopped fodder was provided in wooden feeding mangers available in the shed. All animal husbandry practices were adopted in routine. Availability of common salt was made ensured in the feeding mangers. Flushing ration was formulated (Table I) with crude protein $17.5 \%$ and metabolizable energy 2.8 $\mathrm{Mcal} / \mathrm{kg}$. Breeding season starting from 15 September to 30 October was selected for teasing of both groups of goats. This concentrate was offered @ $250 \mathrm{~g}$ and $500 \mathrm{~g}$ daily one month prior and post breeding season (15 August to 30 November) to $T_{1}$ and $T_{2}$ groups at morning time and fodder was provided ad libitum. On the commencement of breeding season (from 15 September), mating plan of experimental does was designed. Teasing of all exposed does was practiced for half an hour at morning and evening daily to identify the does showing estrus by making proper arrangements to avoid natural mating. Estral does were separated, marked and inseminated with bucks. Animal showing heat signs at morning were mated at same time and repeated at evening also with same buck and vice 
versa. All non-pregnant animals were isolated and pregnant flock of both groups were provided half kilogram of ration named as goat ration (composition is given in Table I) one month prior and post kidding. All necessary arrangements and bedding were provided at kidding time, the birth weights of new born kids were recorded. Starter ration (composition given in Table I) and hay of Lucerne was also provided after 15 days of birth to kids to accelerate the growth. As parasitic diseases in animals cause production losses and several critical issues (Mehmood et al., 2017; Zaman et al., 2017; Ijaz et al., 2018). So, all the animals were dewormed after every four months. Live weights of kids and their dams were recorded at fortnightly basis upto weaning (120 days). Following parameters were recorded in the current study.

Table I. Ingredient and chemical composition of Kid Starter Ration, Goat ration and flushing ration.

\begin{tabular}{|c|c|c|c|}
\hline Ingredients (\%) & $\begin{array}{l}\text { Kid } \\
\text { starter }\end{array}$ & $\begin{array}{l}\text { Flushing } \\
\text { ration }\end{array}$ & $\begin{array}{r}\text { Goat } \\
\text { ration }\end{array}$ \\
\hline Maize grain (crushed) & 22 & 30 & 14 \\
\hline Rape seed meal & - & 5 & - \\
\hline Canola meal & 2 & 5 & 2 \\
\hline Soya bean meal & 9 & - & 4 \\
\hline Rape seed cake & 7 & - & 5 \\
\hline Barley & 3 & - & - \\
\hline Soya husk & 6 & 5 & 12 \\
\hline Palm kernel cake & 6 & 5 & 6 \\
\hline Gluten $60 \%$ & 5 & - & - \\
\hline Gluten $30 \%$ & 8 & 10 & 18 \\
\hline Wheat bran & 22 & 25 & 24 \\
\hline Molasses cane & 8 & 13 & 13 \\
\hline Min.mix + premix & 2 & 2 & 2 \\
\hline Total & 100 & 100 & 100 \\
\hline \multicolumn{4}{|l|}{ Chemical composition } \\
\hline $\mathrm{CP} \%$ & 19.35 & 17.5 & 16.4 \\
\hline TDN\% & 76.00 & 76.35 & 73.2 \\
\hline Fat $\%$ & 3.56 & 3.58 & 3.71 \\
\hline Fibre & 6.67 & 4.79 & 6.2 \\
\hline Energy (ME, MCal $/ \mathrm{kg})$ & 2.72 & 2.82 & 2.78 \\
\hline Ash\% & 7.10 & 6.52 & 6.90 \\
\hline
\end{tabular}

The values are expressed as \% age of dry matter unless otherwise stated. $\mathrm{T}_{1}$ denote control group whereas $\mathrm{T}_{2}$ denote the tested group. $\mathrm{CP} \%$, crude protein percentage; TDN\%, Total digestible nutrient percentage; ME, metabolizable energy, (Mcal/kg DM)
Body weight of does at different physiological state at the start of trial, before flushing, at start of breeding season and at kidding were recorded. Type of birth i.e., single, twin and triplet births were recorded to calculate their percentage. Conception rate, pregnancy rate and kidding percentages were calculated by following formulae:

$$
\begin{gathered}
\text { Conception Rate }=\frac{\text { Total number of does showed estrus }}{\text { Total number of does exposed to buck }} \times 100 \\
\text { Pregnancy Rate }=\frac{\text { Total number of pregnant does }}{\text { Total number of does exposed to buck }} \times 100 \\
\text { Kidding Percentage }=\frac{\text { Total number of kids born }}{\text { Total number of pregnant does }} \times 100
\end{gathered}
$$

Birth weight of kids at birth were recorded and after then fortnightly basis until weaning.

Data of weight of dam (at breeding and at kidding), birth weight and weaning weight of kids were analyzed by using Student's t test at 5\% probability (Snedecor and Cochran 1994) in MINITAB (version 16.1.1.0) and data of type of birth and pregnancy and kidding rate percentages

\begin{tabular}{|c|c|c|c|c|}
\hline Parameter & Group & Mean & $\begin{array}{l}\text { SE } \\
\text { Mean } \\
\end{array}$ & $\begin{array}{l}\text { p- } \\
\text { value }\end{array}$ \\
\hline \multirow{2}{*}{$\begin{array}{l}\text { Weight of dam before } \\
\text { a month of breeding } \\
(\mathrm{kg})\end{array}$} & $\mathrm{T}_{1}$ & 29.18 & 0.21 & \multirow[t]{2}{*}{0.648} \\
\hline & $\mathrm{T}_{2}$ & 28.93 & 0.53 & \\
\hline \multirow{2}{*}{$\begin{array}{l}\text { Weight of dam at } \\
\text { breeding }(\mathrm{kg})\end{array}$} & $\mathrm{T}_{1}$ & 29.52 & 0.14 & \multirow[t]{2}{*}{0.001} \\
\hline & $\mathrm{T}_{2}$ & 31.84 & 0.59 & \\
\hline \multirow{2}{*}{$\begin{array}{l}\text { Weight of dam at } \\
\text { kidding (kg) }\end{array}$} & $\mathrm{T}_{1}$ & 32.46 & 0.18 & \multirow[t]{2}{*}{0.000} \\
\hline & $\mathrm{T}_{2}$ & 37.08 & 0.63 & \\
\hline \multirow{2}{*}{$\begin{array}{l}\text { Birth weight of } \\
\text { kids(kg) }\end{array}$} & $\mathrm{T}_{1}$ & 1.560 & 0.027 & \multirow[t]{2}{*}{0.000} \\
\hline & $\mathrm{T}_{2}$ & 1.870 & 0.040 & \\
\hline \multirow{2}{*}{$\begin{array}{l}\text { Weaning } \\
\text { weight of kids (kg) }\end{array}$} & $\mathrm{T}_{1}$ & 9.00 & 0.21 & \multirow[t]{2}{*}{0.000} \\
\hline & $\mathrm{T}_{2}$ & 10.45 & 0.18 & \\
\hline \multirow{2}{*}{$\begin{array}{l}\text { Weight gain up to } \\
\text { weaning }(\mathrm{kg})\end{array}$} & $\mathrm{T}_{1}$ & 7.44 & 0.20 & \multirow[t]{2}{*}{0.000} \\
\hline & $\mathrm{T}_{2}$ & 8.58 & 0.18 & \\
\hline \multirow{2}{*}{$\begin{array}{l}\text { Av. daily weight gain } \\
\text { (g) }\end{array}$} & $\mathrm{T}_{1}$ & 49.00 & 0.29 & \multirow[t]{2}{*}{0.000} \\
\hline & $\mathrm{T}_{2}$ & 55.91 & 0.41 & \\
\hline
\end{tabular}
of teddy goats were analyzed by chi-square test.

Table II. Effect of flushing on different parameters.

$\mathrm{T}_{1}$ denote control group where as $\mathrm{T}_{2}$ denote the tested group. $\mathrm{g}$ and $\mathrm{Kg}$ represents gram and kilogram. All values are mean \pm SEM.

\section{RESULTS AND DISCUSSION}

Table II shows effects of flushing ration on live weight of does at different physiological stages (at breeding and kidding). It has been observed that there 
was a non-significant difference ( $p$ value $=0.648$ ) of live body weight of does before start of trial. But it has been observed that there was a significant $(p<0.05)$ increase of live body weight of does in $\mathrm{T}_{2}$ group $(31.84 \pm 0.59 \mathrm{~kg})$ than $(29.52 \pm 0.14 \mathrm{~kg})$ in group $\mathrm{T}_{1}$ when flushing ration was provided which may be due to fortification of depleted body reserves and body score. The results of present study showed that the does fed on flushing ration@500 g gained higher body weight $(2.32 \mathrm{~kg})$ as compare to does in control group. This gain in live body weight may due to positive energy balance. Results of present study are in line with Kia et al. (2011) who studied that increase in live body weight in three different breeds of sheep when given high (130\% of the metabolizable energy for maintenance) and moderate (70 \% of the metabolizable energy for maintenance) nutritional supplementation for 6 weeks before mating with grazing on low-nutritive pasture. Naqvi et al. (2011) maintained sheep on pasture with low quality dry herbage along with nutritional supplementation and reported that during period of flushing nutritionally deprive ewes gained weight in an efficient and rapid way. Naqvi et al. (2016) reviewed the relationship between reproduction and nutrition, Furthermore, there is several nutritionally associated signals work as messengers fundamental in reproduction process (Hess et al., 2005).

\section{Table III. Reproductive performances of does.}

\begin{tabular}{lllll}
\hline Parameters & $\mathbf{T}_{\mathbf{2}}$ & $\mathbf{T}_{\mathbf{1}}$ & Chi-Square & $\mathbf{p}$-value \\
\hline $\begin{array}{l}\text { Pregnancy } \\
\text { rate }(\%)\end{array}$ & $(34 \%)$ & $75 \%$ & 1.23 & 0.001 \\
Kidding & $176 \%$ & $(30 / 40)$ & & \\
rate $(\%)$ & $(60 / 34)$ & $(45 / 30)$ & & 0.001 \\
\hline
\end{tabular}

$\mathrm{T}_{1}$ denote control group whereas $\mathrm{T}_{2}$ denote the tested group.

Table III shows significant $\left(\chi^{2}=1.23, \mathrm{p}<0.05\right)$ increase of pregnancy rates of does in $\mathrm{T}_{2}$ group $176 \%$ vs $\mathrm{T}_{1}$ group $150 \%$ when flushing ration was provided. It may be due to better health condition. There is an increase of $26 \%$ fertility in $\mathrm{T}_{2}$ group of goat. Similarly, there was a significant $\left(\chi^{2}=1.31, \mathrm{p}<0.05\right)$ increase of fertility of does in $\mathrm{T}_{2}$ group $85 \%$ vs $75 \%$ in $\mathrm{T}_{1}$ group when flushing ration was provided which may be due to multiple ova shed in goat when flushing ration is given. There is an increase of $10 \%$ in kidding rate when flushing ration was given at higher level. Muthuramalingam et al. (2014) observed similar findings of single, twin and triplet percentage 6.6 $(2 / 30), 46.6(16 / 30)$ and $40(12 / 30)$ respectively in goat. Chaturvedi et al. (2000) reported that the conception rate was higher $(79 \%)$ in flushed ewes as compared to that of non-flushed $(66.7 \%)$. The percentage of kidding was higher in group $\mathrm{T}_{2}$ might be attributed to their higher body weight gain than in the group $T_{1}$. The more percentage of ewes lambed was also reported (Anilkumar et al., 2003) in ewes which weighed heavier at breeding $(92.86 \%)$ than in ewes weighed less at breeding $(86.36 \%)$. Findings of present study are in agreement to that of Kulkarni et al. (2014) who observed that there was an increase of $10 \%$ in kidding rates in Osmanabadi goats when given extra supplementation of $250 \mathrm{~g} /$ doe/day as compared to goats kept on farmer feeding practices. Prasad et al. (2016) also supported the findings of entire study and observed that kidding rate was higher $(20 \%)$ in nutritionally flushed Malabari goats. Reproductive efficiency increased by flushing which boost the ovarian activities i.e., increase in folliculogenesis and higher ovulation rate. Nevertheless, it has been suggested that ovarian responses are dependent on availability of nutrients (De Santiago-Miramontes et al., 2011). There are many factors, i.e., duration of flushing, quality and quantity of feed, condition score of animal and breeding season had an effect on ovulation and finally meant by number of kid produced (Hafez et al., 2011). Moreover, De Santiago-Miramontes et al. (2009) described that activity of estrus and ovulation rate can be stimulated by a moderate to high and constant body condition. Rivas-Muñoz et al., (2010) found that high protein diet can increase ovulation rate in ewes than high-energy ration. Naqvi et al. (2011) reported that feed supplementation or nutritional flushing before mating increases ovulation rates and lambing percentage in many sheep breeds. Acero-Camelo et al. (2008) did flushing of Merino breeds of sheep for three weeks and reported that $23 \%$ higher lambing rate. Chaturvedi et al. (2000) reported that the conception rate was higher $(79.2 \%)$ in flushed ewes as compared to that of non-flushed $(66.7 \%)$.

Table IV shows effect of flushing on birth type. There were higher twins and triplets percentage in $T_{2}$ group than $T_{1}$ group $\left(\chi^{2}=9.138, p<0.05\right)$. This might be due to fact that flushing has effect on super ovulation of does. Consequently, more the ova produced more will be the twining and triplet percentage in goat. This indicates that flushing has influence on fecundity of teddy goats. The results are similar to those of Gunn et al. (1992), Kulkarni et al. (2014) and Prasad et al. (2016) who reported an increase in number of off-springs by flushing prior of does prior breeding. The twin and triplet birth in the Group $T_{2}$ was a clear indication of increased ovulation rate. The occurrence of higher ovulation rate might be correlated with higher body weight gain due to the increased level of concentrate supplementation. An increase of approximately $2 \%$ ovulation rate for every kilogram increase in live weight at mating was recorded in Corriedale, Merino and Romney marsh ewes (Fraser and Stamp, 1987). The number of ova or eggs shed at normal estrus in ewes 
Table IV. Effect of flushing on birth type of teddy goat kids.

\begin{tabular}{|c|c|c|c|c|c|c|c|}
\hline \multirow[t]{2}{*}{ Parameters } & \multirow[t]{2}{*}{ Variable } & & \multicolumn{2}{|c|}{ Groups } & \multirow[t]{2}{*}{ Total } & \multirow[t]{2}{*}{ Chi-square value } & \multirow[t]{2}{*}{ P value } \\
\hline & & & $\mathrm{T}_{2}$ & $\mathrm{~T}_{1}$ & & & \\
\hline \multirow[t]{8}{*}{ Type of birth } & Single & Count & 9 & 15 & 24 & $9.138^{* *}$ & 0.010 \\
\hline & & $\%$ within groups & 15.0 & 20.0 & 17.27 & & \\
\hline & Twins & Count & 42 & 30 & 72 & & \\
\hline & & $\%$ within groups & 70.0 & 80.0 & 74.54 & & \\
\hline & Triplet & Count & 9 & 0 & 9 & & \\
\hline & & $\%$ within groups & 15.0 & 0.0 & 8.18 & & \\
\hline & Total & Count & 60 & 45 & 105 & & \\
\hline & & $\%$ within groups & 100 & 100 & 100 & & \\
\hline
\end{tabular}

$\mathrm{T}_{1}$ denote control group where as $\mathrm{T}_{2}$ denote the tested group.

can vary from one to as many as 9 to 10 (Owen, 1976). The increase twinning in concentrate supplemented group $\mathrm{T}_{2}$ might be due to the higher body weight gain resulting into increased ovulation rate. The increase in litter size (due to twin birth and triplets) as a result of increased body weight due to concentrate supplementation in Horro ewes was also recorded (Galmessa and Prasad, 2002).

Significant differences among control and tested groups on birth weight of kids have been observed. The birth weight of the kids was higher $(\mathrm{p}<0.01)$ in $\mathrm{T}_{2}$ $(1.87 \pm 0.04 \mathrm{~kg})$ than in $\mathrm{T}_{1}(1.56 \pm 0.02 \mathrm{~kg})$ as mentioned in Table II. The birth weight of kids born which were flushed was significantly higher $(\mathrm{p}<0.05)$ than that of control group indicating that good nutrition plane of the does prior to breeding can significantly improve the birth weight their kids. It was revealed that supplementation with $500 \mathrm{~g}$ of concentrate in group $\mathrm{T}_{2}$ was beneficial with respect to birth weight of the kids, as the kids with higher birth weight has the higher prospects of survivability and also related with the future growth of the kids. Our findings are in line with Chaturvedi et al. (2006) who studied that there is an higher birth weight of lambs $(3.47 \mathrm{~kg})$ born from ewes received the concentrate diet @ of 1.5\% of their body weight. Present findings were in agreement to Prasad et al. (2016) who reported that there was an increase of $(1.08 \mathrm{~kg})$ birth weight of Malabari kids due to flushing of does.

A significant difference among control and tested groups has been observed on weaning weight of the kids with the prevision of flushing ration to their dams. The weaning weight of the kids was higher $(\mathrm{p}<0.01)$ in $\mathrm{T}_{2}$ $(10.45 \pm 0.18 \mathrm{~kg})$ than in $\mathrm{T}_{1}(9.0 \pm 0.21 \mathrm{~kg})$ (Table IV). Weight gain was calculated (weaning weight - birth weight). Av. daily weight gain of kids in $\mathrm{T}_{2}(55.91 \pm 0.41 \mathrm{~g})$ observed was higher $(\mathrm{p}<0.01)$ than in group $\mathrm{T}_{1}(49.00 \pm 0.29 \mathrm{~g})$. The findings are analogous to Idris et al. (2011) who reported a significant increase in the average. daily gain of lambs before weaning due to flushing of ewes prior to breeding. Our findings were similar to Prasad et al. (2016), who reported that there was higher gain $(1.78 \mathrm{~kg})$ of weight on weaning of eight week of Malabari kids. It can be concluded that the difference in the mean body weight is only because of the difference in the initial body weight. This indicates long-term carry over effect of flushing on the future body weight gains of kids.

\section{CONCLUSION}

From the results of current study, it can be concluded that the flushing has significant influence on the live weight and reproductive performance of teddy does as well as production performance of their kids.

Statement of conflict of interest

The authors declare no conflict of interest.

\section{REFERENCES}

Acero-Camelo, A., Valencia, E., Rodríguez, A. and Randel, P.F., 2008. Effects of flushing with two energy levels on goat reproductive performance. Livesto. Res. Rural Dev., 20: Article \#136.

Ahmad, F.A., Daghigh, K.H., Hosseinkhani, A., Moghaddam, G., Alijani, S. and Olfati, A., 2014. Investigating the effectiveness of nutrition on the sexual and breeding behaviors in Ghezel sheep. Int J. Adv. Biol. biomed. Res., 2: 715-722.

Anilkumar, R., Iyue, M. and Srinivasan, P., 2003. Reproductive efficiency in high and low body weight Nilgiri ewes subjected to short term flushing and PMSG treatments. Indian J. Anim. Reprod., 24: 24-28. 
Celik, S., 2019. Comparing predictive performances of tree-based data mining algorithms and MARS algorithm in the prediction of live body weight from body traits in Pakistan goats. Pakistan J. Zool., 51: 1447-1456. http://dx.doi.org/10.17582/ journal.pjz/2019.51.4.1447.1456

Chaturvedi, O.H., Bhatta, R., Verma, D.L. and Singh, N.P., 2006. Effect of flushing on nutrient utilization and reproductive performance of ewes grazing on community rangeland. Asian-Aust. J. Anim. Sci., 19: 521-525. https://doi.org/10.5713/ajas.2006.521

Fraser, A. and Stamp, J.T., 1987. Sheep husbandry and disease. 6th Ed. Great Britain., pp. 77-81.

Galmessa, U. and Prasad, S., 2002. Comparative study of PMSG treatment and different levels of concentrate supplements prior to mating on twinning rate of Horro ewes. Indian J. Small Rumin., 8: 39-43.s

GOP 2014. Economic survey of Pakistan 2013-14. Retrieved from [http:// www.finance.gov.pk/ survey/chapters/02-Agriculture14.pdf]

GOP, 2016-2017. Pakistan economic survey. Ministry of Food and Agriculture, Economic Adviser's Wing; Islamabad, Pakistan, pp. 61-62.

Gunn, R.G., Milne, J.A. and Sibbald, A.M., 1992. The effect of feeding supplements in the autumn on the reproductive performance of grazing ewes. Part 1 . Feeding fixed amounts of supplement before and during mating. Anim. Prod., 54: 243-248. https:// doi.org/10.1017/S0003356100036862

Hafez, Y.H., Khalifa, E.I., El-Shafie, M.H., Abdel Khalek, T.M.M., Ahmed M.E. and Shehata E.I., 2011. Effect of energy flushing pre-mating and during mating season on production and reproduction performance of Zaraibi goats. Egyptian J. Sheep Goat Sci., 6: 7- 14.

Hasnain, H.U., 1985. Sheep and goats in Pakistan. FAO Animal Production and Health Paper 56 FAO. Rome.

Hess, B.W., Lake, S.L., Scholljegerdes, E.J., Weston, T.R., Nayigihugu, V., Molle, J.D.C. and Moss, G.E., 2005. Nutritional controls of beef cow reproduction. J. Anim. Sci., 83: E90-E106.

Idris, A.O., Elemam, M.B., Kijora, C., El-Hag, F.M. and Salih, A.M., 2011. Effect of dietary supplementation, sex and birth type on body weight of desert ewes and their lambs growth performance in semi- arid area of Kordofan state Sudan. Livest. Res. Rural Dev., 23: 113-116.

Ijaz, M., Farooqi, S.H., Aqib, A.I., Bakht, P., Ali, A., Ghaffar, A. and Saleem, S., 2018. Seroepidemiology of bovine leptospirosis and associated risk factors in a flood affected zone of Pakistan. Pak. Vet. J.,
38: $179-183$.

Karikari, P.K. and Blasu, E.Y., 2009. Influence of nutritional flushing prior to mating on the performance of West African Dwarf goats mated in the rainy season. Pak. J. Nutr., 8: 1068-1073 https:// doi.org/10.3923/pjn.2009.1068.1073

Kia, H.D., Chapdareh, W.M., Khani, A.H., Moghaddam, G., Rashidi, A., Sadri, H. and Alijani, S., 2011. Effects of flushing and hormonaltreatment on reproductive performance of Iranian Markhoz goats. J. Anim. Physiol. Anim. Nutr., 96:1157-64.

Kulkarni, P., Veeranna, K.C., Rao, R.B. and Mageppa, H., 2014. Effect of supplementary feeding in osmanabadi goats: a participation action research analysis from India. Int. J. Agric. Ext., 2: 205-210.

Kusina, N.T., Chinuwo, T., Hamudikuwanda, H., Ndlovu, L.R. and Muzanenhamo, S., 2001. Effect of different dietary energy level intakes on efficiency of estrus synchronization and fertility in Mashona goat does. Small. Rumin. Res., 39: 283-288 https:// doi.org/10.1016/S0921-4488(00)00192-9

Kuthu, Z.H., Javed, K., Babar, M.E., Sattar, A. and Abdullah, M., 2013. Environmental effects on growth traits of teddy goats. J. Anim. Pl. Sci., 23: 692-698

López, A., 2004. Multiple factors affecting the efficiency of multiple ovulation and embryo transfer in sheep and goats. Reprod. Fertil. Develop., 16: 421-35. https://doi.org/10.1071/RD04033

Mehmood, K., Zhang, H., Sabir, A.J., Abbas, R.Z., Ijaz, M., Durrani, A.Z., Saleem, M.H., Rehman, M., Iqbal, M.K., Wang, Y., Ahmad, H.I., Abbas, T., Hussain, R., Ghori, M.T., Ali, S., Khan, A.U. and Li, J., 2017. A review on epidemiology, global prevalence and economical losses of fasciolosis in ruminants. Microb. Pathog., 109: 253-262. https:// doi.org/10.1016/j.micpath.2017.06.006

Miramontes, D.S., Malpaux, M.A. and Delgadillo, J.A., 2009. Body condition is sociated with a shorter breeding season and reduced ovulation rate in subtropical goats. Anim. Reprod. Sci., 114: 175-182. https://doi.org/10.1016/j.anireprosci.2008.09.001

Miramontes, D.S., Véliz-Deras, M.A., Mellado, F.G., Luna-Orozco, M., Meza-Herrera, J.R., RivasMuñoz, R., Carrillo, E. and Mellado, M., 2011. The effect of flushing and stimulus of estrogenized does on reproductive performance of anovulatory-range goats. Trop. Anim. Hlth. Prod., 43: 1595-1600. https://doi.org/10.1007/s11250-011-9849-6

Muthuramalingam, T., Pothiappan, P., Gnanaraj, P.T., Devi, T. and Rangasamy, S., 2014. Effect of flushing on reproductive performance and 
synchronization of estrus in tellicherry does. Indian J. Anim. Reprod., 35: 34-35.

Naqvi, S.M.K., Sejian, V. and Karim S.A., 2013. Effect of feed flushing during summer season on growth,reproductive performance and blood metabolites in Malpuraewes under semiarid tropical environment. Trop. Anim. Hlth Prod., 45:143-148. https://doi.org/10.1007/s11250-012-0185-2

Naqvi, S.M.K., Soren, N.M. and Karim, S.A., 2011. Effect of concentrate supplementation on performance, ovarian response, andsome biochemical profile of Malpura ewes. Trop. Anim. Hlth Prod., 43: 905-913. https://doi.org/10.1007/ s11250-011-9782-8

Owen, J.B., 1976. Sheep production. Bailliere Tindal, London. pp. 184-185.

Prasad, K., John, C. and Sunanda, C., 2016. Effect of nutritional flushing on the birth weight and body weight gain of malabari kids. Int. J. Sci. Nat., 7: 533-536.

Rivas-Muñoz, R.E., Carrillo, E., Rodriguez, R., Leyva, C., Mellado, M. and Véliz, F.G., 2010. Effect of body condition score of does and use of bucks subjected to added artificial light on estrus response of Alpine goats. Trop. Anim. Hlth. Prod., 42: 12851289.

Robinson, J.J., Ashworth, C.J. and Rooke J.A., 2006. Nutrition and fertility in ruminant livestock. Anim.
Feed. Sci. Tech., 126: 259-276.

Smith, O.B. and Akinbamijo, O.O., 2000. Micronutrients and reproduction in farm animals. Anim. Reprod. Sci., 60: 549-560. https://doi.org/10.1016/S03784320(00)00114-7

Snedecor, G.W. and Cochran, W.G., 1994. Statistical methods. 8th edn, Iowa State University Press, Ames, Iowa, USA.

Titi, H.H., Alnimer, M., Tabbaa, M.J. and Lubbadeh, W.F., 2008. Reproductive performance of seasonal ewes and does fed dry fat during their postpartum period. Livest. Sci., 115: 34-41. https://doi. org/10.1016/j.livsci.2007.06.006

Younas, M. and Yaqoob, M., 2005. Feed resources of livestock in the Punjab, Pakistan. Livest. Res. Rural Dev., 17: 2005

Zaman, M.A., Rehman, T.U., Abbas, R.Z., Babar, W., Khan, M.N., Riaz, M.T., Hussain, R., Ghauri, T. and Arif, M., 2017. Therapeutic potential of Ivermectin, doramectin and trichlorophan against Psoroptes ovis in sheep and cattle of Cholistan. Pak. Vet. J., 37: 233-235.

Zubair, M.M., Ahmad, M., Saleemi, K., Gul, S.T., Ahmad, N. and Umar, S., 2016. Protective effects of vitamin E on sodium arsenite-induced toxicity, testicular measurements and histopathological studies of testes in teddy goat bucks. Andrologia, 49: https://doi.org/10.1111/and.12699 